Number 2

\title{
POTENSI EKSTRAK KULIT BUAH DELIMA TERHADAP PERTUMBUHAN Candida albicans SECARA IN VITRO
}

Putu rina Widhiasih ${ }^{1}$, I Nyoman Jirna ${ }^{2}$, IGA. Sri Dhyanaputri ${ }^{3}$

\begin{abstract}
Background: Infection by the Candida albicans has increased globally and reported fungal resistance to synthetic antifungal. It is, therefore, necessary to develop effective antifungal medicines for the treatment of infection by Candida albicans.

Purpose: This study aims to determine the content of phytochemical and inhibitory power of pomegranate skin extract on Candida albicans growth.

Methode: This research type is the true experiment with post test only control design. The method used for the phytochemical test is qualitative tube method. Pomegranate skin resistivity test on Candida albicans growth was done by disc diffusion method. The pomegranate skin is tested at concentrations of 100\%, 75\%, 50\%, 25\% and 10\%. Negative control with $96 \%$ alcohol and positive control using ketocenazole $2 \%$.

Result: The results of phytochemical tests showed pomegranate skin extract containing saponins, tannins, and flavonoids. Pomegranate skin extracts are not able to inhibit the growth of Candida albicans by disc diffusion method.

Conclusion:The conclusion of this study is pomegranate skin extracts can not inhibit Candida albicans growth, For other researchers which use jatropha curcas twigs, are suggested to do a phytochemical test quantitatively and to test the antifungal potential with liquid DMSO 10\%, kloroform and petroleum eter.
\end{abstract}

Keywords:Potential antifungal, pomegranate skin extract, Candida albicans

\section{PENDAHULUAN}

$\begin{array}{ccc}\text { Pengobatan } & \text { terhadap infeksi } \\ \text { kandidiasis biasanya } & \text { ditangani } & \text { dengan }\end{array}$ antifungi nistatin topikal, ketokonazol atau flukonazol oral. Kandidiasis sistemik diterapi dengan amfoterisin $\mathrm{B}$ yang pada kasus tertentu ditambah dengan flusitosin, flukonazol atau caspofungin oral ${ }^{1}$. Hasil beberapa studi menunjukkan bahwa adanya peningkatan resistensi Candida terhadap anti jamur. Hasil penelitian menemukan adanya kasus resistensi jamur Candida albicans terhadap antifungi flukonazol pada pasien DM tipe 2 di RSUD Banda Aceh sekitar 9,7\% resisten dan $16,1 \%$ intermediet ${ }^{2}$. Pengobatan dari infeksi jamur ini tidak terlalu banyak dikembangkan dan kasus infeksi ini berkembang sangat pesat. Hal itu mendorong peneliti untuk mengembangkan pengobatan terhadap infeksi jamur dengan menggunakan pengobatan dari tanaman herbal, selain karena mudah didapatkan juga memiliki resiko rendah terhadap kesehatan manusia jika dikonsumsi. 
Delima (Punica granatum L.) merupakan salah satu tanaman obat yang unik karena semua bagian tumbuhan tersebut memiliki kandungan kimia yang berguna untuk kesehatan mulai dari akar, batang, daun, buah, dan biji. Pada penelitian ini digunakan kulit huah delima karena memiliki kandungan alkaloid, saponin, flavonoid, tanin yang mempunyai aktivitas antifungi ${ }^{3}$.

Penelitian ini bertujuan untuk mengetahui kandungan metabolit sekunder dan potensi antifungi ekstrak kulit buah delima (Punica granatum L.) terhadap daya hambat pertumbuhan jamur Candida albicans.

\section{METODE}

Jenis Penelitian ini adalah true experiment dengan rancangan penelitian posttest only control design ${ }^{4}$. Besar sampel yaitu 30 sampel, didapatkan dengan membuat lima perlakuan konsentrasi ekstrak kulit buah delima (10\%, 25\%, 50\%, 75\%, dan 100\%). Jumlah ulangan yang dilakukan pada penelitian sebanyak tiga kali untuk masing-masing konsentrasi dan dua kali replikasi, ditambah dengan kontrol positif (ketokenazol 2\%) dan kontrol negatif (alkohol 96\%) ${ }^{5}$.

$$
\text { Penelitian ini dilakukan di }
$$
laboratorium farmasi Fakultas MIPA untuk analisis fitokimia dan laboratorium
Mikrobiologi Fakultas Kedokteran Universitas Udayana untuk uji potensi antifungi. Pengumpulan data dilakukan oleh peneliti dengan metode pemeriksaan laboratorium, dengan prosedur kerja meliputi tahapan : persiapan alat dan media, pembuatan ekstrak dengan metode maserasi, analisis fitokimia secara kualitatif , pembuatan kosentrasi ekstrak, dan pemeriksaan potensi antifungi dengan difusi cakram

Data yang diperoleh dalam penelitian ini kemudian dikelompokkan dalam bentuk tabel dan diberi narasi. Kemudian dilakukan analisis dengan uji Anova untuk mengetahui perbedaan daya hambat potensi antifungi ektrak kulit buah delima pada jamur Candida albican pada berbagai konsentrasi,

\section{HASIL}

\section{Uji fitokimia}

Hasil uji fitokimia menunjukkan bahwa ekstrak kulit buah delima mengandung senyawa flavonoid, saponin, dan tanin serta tidak mengandung senyawa alkaloid.pada tangkai jarak pagar ( tabel 1). 
Tabel 1

Hasil Uji Fitokimia Ekstrak Kulit Buah Delima

\begin{tabular}{|c|c|c|c|c|}
\hline No & $\begin{array}{l}\text { Identifikasi } \\
\text { zat }\end{array}$ & Reagen & Hasil & Interpretasi Hasil \\
\hline 1 & Flavonoid & $\begin{array}{ll}\text { 1. } & \text { Oksalat } \\
\text { 2. } & \text { Borat } \\
\text { 3. } & \text { Eter } \\
\end{array}$ & Berflouresensi Kuning & $\begin{array}{l}\text { Positif (terdapat Flavonoid } \\
\text { pada ekstrak) }\end{array}$ \\
\hline 2 & Saponin & $\begin{array}{l}\text { 1. Aquadest } \\
\text { 2. } \mathrm{HCl}\end{array}$ & $\begin{array}{l}\text { Terbentuk Busa } 1-10 \mathrm{~cm} \\
\text { selama } 10 \text { menit }\end{array}$ & $\begin{array}{l}\text { Positif (terdapat Saponin } \\
\text { pada ekstrak) }\end{array}$ \\
\hline 3 & Alkaloid & $\begin{array}{l}\text { 1. } \mathrm{HCl} \\
\text { 2. Pereaksi : } \\
\text { a. Meyer } \\
\text { b. Dragendorff } \\
\text { c. Wagner }\end{array}$ & $\begin{array}{l}\text { a. Tidak terbentuk endapan } \\
\text { putih } \\
\text { b. Tidak terbentuk endapan } \\
\text { jingga } \\
\text { c. Tidak terbentuk endapan } \\
\text { coklat kehitaman }\end{array}$ & $\begin{array}{l}\text { Negatif ( tidak terdapat } \\
\text { Alkaloid pada ekstrak) }\end{array}$ \\
\hline 4 & Tanin & $\mathrm{Pb}$ & Endapan Putih & $\begin{array}{l}\text { Positif (terdapat Tanin } \\
\text { pada ekstrak) }\end{array}$ \\
\hline
\end{tabular}

2.Uji potensi antifungi

Hasil perlakuan ekstrak kulit buah delimar konsentrasi 10\%, 25\%, 50\%, 75\% dan $100 \%$ terhadap Candida albicans pada pemeriksaan replikasi pertama dan kedua dengan keseluruhan pengulangan menunjukkan tidak ada potensi daya hambat, dengan nilai rata-rata $0 \mathrm{~mm}$ (tabel 2).

Tabel 2

Diameter Zona Hambat Pertumbuhan Candida albicans pada Ekstrak Kulit Buah Delima

\begin{tabular}{|c|c|c|c|c|c|c|c|c|}
\hline \multirow{2}{*}{ Replikasi } & \multirow{2}{*}{ Pengulangan } & \multicolumn{5}{|c|}{ Zona Hambat } & \multicolumn{2}{|c|}{ Kontrol } \\
\hline & & $10 \%$ & $25 \%$ & $50 \%$ & $75 \%$ & $100 \%$ & $(+)$ & $(-)$ \\
\hline \multirow{3}{*}{ I } & 1 & 0 & 0 & 0 & 0 & 0 & 27 & 0 \\
\hline & 2 & 0 & 0 & 0 & 0 & 0 & 28 & 0 \\
\hline & 3 & 0 & 0 & 0 & 0 & 0 & 25 & 0 \\
\hline \multirow{3}{*}{ II } & 1 & 0 & 0 & 0 & 0 & 0 & 26 & 0 \\
\hline & 2 & 0 & 0 & 0 & 0 & 0 & 27 & 0 \\
\hline & 3 & 0 & 0 & 0 & 0 & 0 & 23 & 0 \\
\hline \multicolumn{2}{|c|}{ Rata-rata } & 0 & 0 & 0 & 0 & 0 & 26 & 0 \\
\hline
\end{tabular}


3. Analisis data

Analisis statistika perbedaan potensi daya hambat pertumbuhan Candida albicans terhadap berbagai konsentrasi ekstrak tidak dapat dianalisis karena tidak adanya nilai propbability setelah dilakukan analisis data, sehingga uji beda tidak dapat ditentukan. Hal ini dikarenakan tidak adanya varian dari nilai diameter zona hambat, maka dilakukan analisis perbedaan antara kontrol positif dengan perlakuan kosentrasi ekstrak . Setelah dilakukan pengujian diperoleh hasil nilai $p<\alpha(0,000<0,05)$, yang menandakan data berdistribusi tidak normal, kemudian dilanjutkan uji beda dengan Mann-Whitney diperoleh hasil nilai probabilitas $p(0,003)<\alpha(0,05)$ yang menandakan bahwa ada perbedaan antara kontrol positif dengan perlakuan $10 \%$, $25 \%, 50 \%, 75 \%$ dan $100 \%$ ekstrak tangkaidaun pagar.

\section{PEMBAHASAN}

Berdasarkan hasil penelitian senyawa metabolit sekunder dari ekstrak kulit buah delima yaitu saponin, tannin, flavonoid, dan tidak terdapat alkaloid. Hasil uji daya hambat ekstrak kulit buah delima dengan metode difusi cakram menunjukkan tidak terbentuk zona hambat pada konsentrasi 10\%, 25\%, 50\%, 75\% dan $100 \%$ terhadap pertumbuhan Candida albicans. Hal ini menunjukkan bahwa ekstrak kulit buah delima tidak mampu menghambat pertumbuhan Candida albicans. Berbagai faktor dapat mempengaruhi kondisi tersebut antara lain adalah jenis dan konsentrasi zat aktif yang terdapat pada ekstrak kulit buah delima. Hasil uji fitokimia menunjukkan tidak terdapat alkaloid yang dapat bekerja dengan cara menghambat kerja membran sterol (ergosterol) sehingga mengganggu pertumbuhan Candida albicans. Senyawa ini akan berikatan kuat dengan ergosterol dan membentuk lubang sehingga menyebabkan kebocoran membran sel dan dinding sel jamur sehingga ion $\mathrm{K}$, fosfat anorganik, asam karbosilat, asam amino dan ester fosfat keluar dari dalam sel jamur. Kebocoran ini merupakan kerusakan tetap pada sel yang menyebabkan kematian dari sel jamur ${ }^{6}$.

Ekstrak kulit buah delima mengandung senyawa metabolit sekunder yang bersifat antifungi yaitu flavonoid, saponin dan tanin, walaupun memiliki senyawa antifungi tersebut namun ekstrak kulit buah delima tidak mampu menghambat pertumbuhan Candida albicans yang disebabkan karena senyawa metabolit sekunder dari golongan flavonoid dalam ekstrak ini yang tersari bukan berasal dari golongan flavanon dan flavan yang dapat menghambat pertumbuhan jamur yaitu dengan 
mengambat sintesis asam nukleat jamur, Flavonoid juga dapat menghambat pembelahan dan poliferasi dari sel jamur 6,7 . Senyawa tanin yang terdapat dalam ekstrak ini senyawa tanin terhidrolisis yang memiliki daya antifungi yang dapat menciutkan dan mengendapkan protein dari larutan dengan membentuk senyawa yang tidak larut, namun jumlah tanin dalam ekstrak ini belum cukup untuk menghambat pertumbuhan Candida albicans ${ }^{8,9}$. Fungsi lain tanin sebagai antifungi yaitu mampu menghambat aktivitas enzim glikosiltransferase. Enzim Glikosiltransferase mengkatalisis transfer gugus gula dari molekul donor ke molekul akseptor aktif dan membentuk ikatan glikosidik yang berfungsi untuk menghubungkan sejumlah besar unit monosakarida menjadi polisakarida. Komposisi dari dinding sel jamur Candida albicans adalah berbagai jenis polisakarida, sehingga jika enzim ini diganggu maka dinding sel Candida albicans akan terganggu integritasnya ${ }^{10}$. Senyawa saponin yang terdapat dalam ekstrak kulit buah delima tidak cukup jumlahnya dalam merusak dinding sel Candida albicans dikarenakan komposisi penyusun dinding sel yang mengandung gula terlalu banyak. Fungsi dari senyawa saponin yaitu dapat membentuk pori pada dinding sel jamur sehingga integritas sel jamur akan hilang ${ }^{11}$.
Selain itu tidak terbentuknya zona hambat dalam penelitian ini dapat dipengaruhi oleh faktor teknis seperti jenis pelarut yang digunakan kurang sesuai sehingga zat aktif tidak berdifusi dengan baik ke dalam media. Untuk dapat menghambat pertumbuhan Candida albicans diperlukan jumlah senyawa metabolit yang lebih banyak dan lebih spesifik dibandingan untuk menghambat mikroba lainnya karena sistem pertahanan dari Candida albicans yang cukup kuat. Pertahanan dari jamur ini dapat dilihat dari struktur dinding sel yang terdiri dari 5 lapisan, kemudian memiliki lapisan membran plasma yang bagian luarnya terdiri dari lipid serta adanya membran ergosterol yang merupakan membran fosfolipid ganda yang dapat menahan lisis akibat tekanan osmotik. Sifat dari Candida albicans pada suhu $37^{\circ} \mathrm{C}$ dapat membentuk Clamydospora yang memiliki dinding spora yang sangat tebal dan kuat sehingga sulit ditembus oleh senyawa metabolit sekunder. berbeda dengan antibakteri, bakteri termasuk kelompok prokariota sehingga sel yang menjadi target antibakteri tidak dijumpai pada sel mamalia, sehingga perkembangan obat antibakteri lebih maju dibanding obat antijamur $^{12}$. 


\section{SIMPULAN DAN SARAN}

\section{Simpulan}

Kandungan fitokimia yang terdapat dalam ekstrak kulit buah delima menunjukkan hasil positif adanya senyawa tanin, flavonoid dan saponin sementara untuk senyawa alkaloid menunjukkan hasil negatif. Diameter daya hambat ekstrak kulit buah delima dengan konsentrasi 10\%, $25 \%, 50 \%, 75 \%$ dan $100 \%$ terhadap pertumbuhan jamur Candida albicans diperoleh hasil $0 \mathrm{~mm}$. Terdapaat perbedaan pertumbuhan jamur Candida albicans pada ekstrak kulit buah delima dengan kontrol positif setelah dilakukan uji statistika.

\section{Saran}

Adapun saran yang ingin disampaikan melalui tulisan ini, kepada peneliti lain untuk melanjutkan penelitian ini dengan mengukur kadar dari kandungan metabolit sekunder yang terdapat dalam ekstrak kulit buah delima secara kuantitatif serta melakukan uji aktivitas antifungi dengan pelarut yaitu DMSO 10\%, kloroform dan petroleum eter.

\section{DAFTAR PUSTAKA}

1. Jawetz, Melnick dan Adelberg.. Mikrobiologi Kedokteran Edisi 25. Alih Bahasa : Geo F. Brooks; Karen C. Caroll; Janet S. Butel; Stephen A.Morse; Timothy A. Mietzner. Jakarta: EGC. 2012

2. Rezeki, S., Z. Mubarak dan I. Syuhada. Gambaran Sensitivitas Isolat Candida Albicans Oral Terhadap Nistatin Dan Flukonazol Pada
Pasien Diabetes Melitus Tipe 2 Di Rsudza Banda Aceh. Cakradonya Dental Journal. 5(1): 523-533. 2013.

3. Duryatmo, S, Herbal Indonesia Berkhasiat Bukti Ilmiah \& Cara Racik. Jakarta: PT Trubus Swadaya. 2010.

4. Noor, Metodologi Penelitian, Jakarta: Kencana Group 2011.

5. Hanafiah, K.A. Rancangan Percobaan Aplikatif, Jakarta: PT Raja Grafindo Persada. 2005.

6. Bhaskara, G.Y. Uji Daya Antifungi Ekstrak Etanol Daun Salam (Syzygium Polianthum [Wight] Walp.) Terhadap CandidaAlbicans Atcc 10231 Secara In Vitro. Tersedia dalam http://onesearch.id/Record/IOS2728.22008?wi dget $=1 \&$ repository_id=2554\#details. diakses 6 Juni 2017, 18.23 WITA. 2012.

7. Cushnie, T.P., dan A.J. Lamb. Antimicrobial activity of flavonoids. International Journal of Antimicrobial Agents.; 26(5): 343-56. 2005

8. Lim, S.H., I. Darah, and K. Jain. Antimicrobial activities of tannins extracted from Rhizophora apiculata Barks. Journal of Tropical Forest Science. 18(1): 59-65. 2006.

9. Ansari M.A., A. Anurag, Z.Fatima dan S.Hameed. Natural Phenolic Compounds: A Potential Antifungal Agent.Microbial pathogens and strategies for combating them: science, technology and education. 1(1): 1189: 1195. 2013.

10. Maharani, S., O. Santoso. Pengaruh Pemberian Larutan Ekstrak Siwak (Salvadora persica) pada berbagai konsentrasi terhadap pertumbuhan Candida albicans. Jurnal PDGI. 61(2): 61-64. 2012.

11. Turkey, M. dan Figen. Saponins versus plant fungal pathogens. Journal of Cell \& Molecular Biology. 5(1): 13-17. 2006.

12. Amelia, S. 2011. Obat Anti Jamur (Fungal), tersedia dalam http://repository.usu.ac.id/bitstream/handle/12 3456789/30412/Kemoterapi\%20Anti\% 20Jam ur.pdf?sequence $=1 \&$ is Allowed=ydiakses tanggal 19 Juni 2017 